\title{
Genetic Variation in the Tau Kinases Pathway May Modify the Risk and Age at Onset of Alzheimer's Disease
}

José Luis Vázquez-Higuera ${ }^{\mathrm{a}}$, Ignacio Mateo ${ }^{\mathrm{a}}$, Pascual Sánchez-Juan ${ }^{\mathrm{a}}$, Eloy Rodríguez-Rodríguez ${ }^{\mathrm{a}}$, Ana Pozueta $^{\mathrm{a}}$, Miguel Calero ${ }^{\mathrm{b}}$, José Luis Dobato ${ }^{\mathrm{c}}$, Ana Frank-García ${ }^{\mathrm{d}}$, Fernando Valdivieso ${ }^{\mathrm{e}}$, José Berciano ${ }^{\mathrm{a}}$, Maria J. Bullido ${ }^{\mathrm{e}}$ and Onofre Combarros ${ }^{\mathrm{a}, *}$

${ }^{a}$ Neurology Service and CIBERNED, "Marqués de Valdecilla" University Hospital (University of Cantabria and IFIMAV), Santander, Spain

${ }^{\mathrm{b}}$ Spongiform Encephalopathies Unit, National Microbiology Centre and CIBERNED, Carlos III Health Institute, Madrid, Spain

${ }^{\mathrm{c}}$ Alzheimer Disease Research Unit, CIEN Foundation, Carlos III Health Institute, Alzheimer Center Reina Sofia Foundation, Madrid, Spain

${ }^{\mathrm{d}}$ Neurology Service and CIBERNED, Hospital Universitario La Paz (U.A.M.), Madrid, Spain

${ }^{\mathrm{e}}$ Molecular Biology Department and CIBERNED, Centro de Biología Molecular Severo Ochoa (C.S.I.C.-U.A.M.), Madrid, Spain

\begin{abstract}
Tau abnormal hyperphosphorylation and the formation of neurofibrillary tangles in the Alzheimer's disease (AD) brain is the result of upregulation of tau kinases. In a group of 729 Spanish late-onset AD patients and 670 healthy controls, we examined variations into a set of 20 candidate genes of kinases involved in tau phosphorylation at AD-related sites (PRKACB; CAMK2A; MARK1, 2, 3 and 4; CSNK1D; CDC2; RPS6KB1 and 2; p38 $\alpha$ and $\beta$; IB1; JNK1, 2 and 3; MEK1 and 2; ERK1 and 2), to address hypotheses of genetic variation that might influence both AD risk and age at disease onset. There was an increased frequency of RPS6KB2 (intron 2, rs917570) minor allele in patients (50\%) versus controls (39\%) $(\mathrm{OR}=1.52 ; 95 \%$ CI 1.30-1.77; $p=1.24 \times 10^{-5}$ Bonferroni corrected), and the presence of this minor allele was significantly $\left(p=4.2 \times 10^{-5}\right)$ associated with a 3-years later onset of $\mathrm{AD}$ (mean age 74.1 years) when compared to age at onset of non-minor allele carriers (mean age 71.1 years). In APOE non- $\varepsilon 4$ allele carriers, the combined effect of AD-associated risk alleles from the genes of CDC2, RPS6KB1 and 2, p38 $\alpha$, JNK (1, 2 and 3), MEK2, and ERK2 was significantly $(p=0.002)$ associated with a late-onset (>76 years) of AD. The CDC2 AGC haplotype derived from SNPs in introns 3 (rs2448347), 5 (rs2456772), and 7 (rs1871447) showed a protective effect against AD in APOE non- $\varepsilon 4$ allele carriers (permutation $p=1.0 \times 10^{-4}$ ) with a frequency of $9 \%$ in cases and $15 \%$ in controls. Common genetic variation in the tau kinases pathway does underlie individual differences not only in susceptibility to AD but also in disease phenotype (age at disease onset).
\end{abstract}

Keywords: Alzheimer's disease, kinases, phosphorylation, polymorphism, tau

\section{INTRODUCTION}

${ }^{*}$ Correspondence to: Onofre Combarros, Neurology Service, Marqués de Valdecilla University Hospital, Avda. Valdecilla s/n, 39008 Santander, Spain. Tel.: +34 942 202507; Fax: +34 942 202655; E-mail: combarro@unican.es.
One of the neuropathological hallmarks in Alzheimer's disease (AD) is neurofibrillary tangles (NFTs), which are composed of the microtubulebinding protein tau that is hyperphosphorylated [1-3]. 
Tau abnormal hyperphosphorylation is the result of upregulation of tau kinases, and GSK3- $\beta$ and CDK5 are among the kinases most implicated in the abnormal hyperphosphorylation of tau in AD brains [3]. The inhibition of abnormal hyperphosphorylation of tau is one of the most promising therapeutic targets for the development of disease modifying drugs, and it has been suggested that inhibition of either both GSK3- $\beta$ and CDK5 or one of these two kinases plus PRKA or CAMK2 might be required to inhibit AD neurofibrillary degeneration [4]. All this data postulates a role for tau kinases as interesting genetic targets for association analysis of $\mathrm{AD}$. We have previously examined the contribution of some tau kinases genes such as GSK3- $\beta$ [5], CDK5 [6], CDK5R1 [7], DYRK1A [8], and TTBK1 [9] to the susceptibility to AD. In the present study, we extended previous investigations by evaluating variations into an exhaustive list of all known genes of kinases involved in tau phosphorylation at AD-related sites, in relation to both AD risk and age at disease onset, in a Spanish cohort.

\section{METHODS}

\section{Subjects}

The study included 729 AD patients (67\% women; mean age at study 77.2 years; SD 8.0; range 61-103 years; mean age at onset 73.3 years; SD 7.8; range 60-100 years) who met NINCDS/ADRDA criteria for probable AD [10]. All AD cases were defined as sporadic because their family history did not mention any first-degree relative with dementia. AD patients were recruited from the Departments of Neurology of University Hospital "Marqués de Valdecilla" (Santander, Spain) and Hospital "La Paz" (Madrid, Spain), and from Alzheimer Center Reina Sofia Foundation (Madrid, Spain). The large majority of patients was living in the community and had been referred by their general practitioner; few had been admitted from hospital wards or nursing home facilities. Control subjects were 670 unrelated individuals $(64 \%$ women; mean age 78.3 years; SD 9.4; range 60-104 years) randomly selected from nursing homes. These subjects had complete neurologic and medical examinations that showed that they were free of significant illness and had Mini Mental State Examination scores of 28 or more, which were verified by at least one subsequent annual following-up assessment. The controls arose from the same base population as the cases. The AD and control samples were Caucasians orig- inating from a limited geographical area in northern Spain (Santander) and from the central area of Spain (Madrid).

\section{Genotyping}

Blood samples were taken after written informed consent had been obtained from the subjects or their representatives. The study was approved by the ethical committees of the University Hospital "Marqués de Valdecilla", Alzheimer Center Reina Sofia Foundation, and the Hospital "La Paz". Genotyping of cAMP-dependent kinase A catalytic subunit $\beta$ (PRKACB), calmodulin-dependent protein kinase-II $\alpha$ (CAMK2A), microtubule-affinity regulating kinases (MARK1, 2, 3 and 4), casein kinase-1 $\delta$ (CSNK1D), cell division cycle 2 kinase (CDC2), ribosomal S6 protein kinases (RPS6KB1 and 2), p38 $\alpha$ and $\beta$, isletbrain $1 / \mathrm{C}$-Jun $\mathrm{N}$-terminal kinase interacting protein 1 (IB1), C-Jun N-terminal kinases (JNK1, 2 and 3), MEK1 and 2, and extracellular signal-regulated kinases (ERK1 and 2) was performed using the iPLEX Gold assay on the MassArray system (Sequenom Inc., San Diego, USA). We used data from the HapMap project (http://www.hapmap.org) to select htSNPs capturing $92 \%$ of PRKACB genetic variability, $91 \%$ of CAMK2A, $91 \%$ of MARK $1,90 \%$ of MARK2, $89 \%$ of MARK $3,91 \%$ of MARK $4,100 \%$ of CSNK1D, $90 \%$ of CDC2, 93\% of RPS6KB1, $100 \%$ of RPS6KB2, 91\% of p $38 \alpha, 100 \%$ of p $38 \beta, 100 \%$ of IB $1,92 \%$ of JNK $1,88 \%$ of JNK2, 87\% of JNK3, 80\% of MEK1, 90\% of MEK2, $100 \%$ of ERK1, and $93 \%$ of ERK2 genetic variability in Caucasians. SNPs were chosen among those with minor allele frequencies $\geq 5 \%$ using Haploview v3.2 software (http://www.broad.mit.edu/mpg/haploview) with an $r^{2}$ threshold of 0.8 .

\section{Statistical analysis}

Hardy-Weinberg equilibrium (HWE) was calculated for the htSNPs in the control population using Pearson's $\chi^{2}$ statistics. We assessed pairwise linkage disequilibrium (LD) between the htSNPs by D' and $r^{2}$ statistics. Haplotype reconstruction and their frequencies in cases and controls were estimated by an expectation-maximization algorithm, method implemented in Haploview 3.32. Pearson's $\chi^{2}$ statistics were performed to compare allele and haplotype distribution of the patients and control for each htSNP. Allelic distributions were assessed by logistic regression using the package SPSS 13.0 for Windows (SPSS, Inc, Chicago, Illinois). In order to obtain a measure 
of significance corrected for multiple testing, we used Bonferroni's method to correct our nominal $p$-values for all 85 tests performed, corresponding to the 85 SNPs analyzed. In our haplotype analysis we chose a less conservative approach, permutation test, to adjust for multiple testing. By using Student's t test and stratifying by APOE $\varepsilon 4$ allele status, we tested for differences in age at disease onset depending on allele distributions of the AD-associated risk SNPs. In addition, we calculated for each subject a cumulative genetic risk score (GRS) defined as the number of nominally significant $(p<0.05) \mathrm{AD}$-associated risk alleles from our list of tau kinases pathway genes, and we correlated the GRS with age at AD onset using Pearson's $r^{2}$; moreover, we compared by ANOVA test the GRS distributions across patient's age at disease onset divided into quintiles.

\section{RESULTS}

PRKACB rs7515976 and rs11163911, CAMK2A rs6881743, MARK2 rs11231637, MARK4 rs344807, CSNK1D rs12601586, CDC2 rs3213058, RPS6KB1 rs180523, p38ß rs742186, JNK2 rs6868333, MEK2 rs350896 and ERK1 rs11865086 SNPs were significantly deviated from HWE, and therefore, they were excluded from the analysis; these deviations could be the result of a genotyping error. As shown in Table 1, the distribution of the minor allele frequencies of the tau kinases genes did not differ significantly between AD and control groups, except for RPS6KB2 (intron 2, rs917570) minor allele that was increased in patients $(50 \%)$ versus controls $(39 \%)(\mathrm{OR}=1.52$; 95\% CI 1.30-1.77; $p=1.24 \times 10^{-5}$ Bonferroni corrected). Haplotype distributions were not significantly different between cases and controls in the overall analysis or after stratification by APOE $\varepsilon 4$ allele, except for CDC2 gene (Table 2): the AGC haplotype derived from SNPs in introns 3 (rs2448347), 5 (rs2456772), and 7 (rs1871447) showed a protective effect against $\mathrm{AD}$ only in APOE $\varepsilon 4$ allele noncarriers (permutation $p=1.0 \times 10^{-4}$ ), with a frequency of $9 \%$ in cases and $15 \%$ in controls.

Age of AD onset was 3 years later (mean age 74.13, SD 7.51) in patients carrying RPS6KB2 (intron 2, rs917570) minor allele compared to non-minor allele carriers (mean age 71.16, SD $8.22 ; p=4.2 \times 10^{-5}$ ), with this significant association being equally present in APOE $\varepsilon 4$ allele carriers $(p=0.006)$ and APOE non- $\varepsilon 4$ allele carriers $(p=0.002)$. We selected 9 htSNPs (CDC2 rs1871447,
RPS6KB1 rs8071475, RPS6KB2 rs917570, p38 $\alpha$ rs851019, JNK1 rs10857565, JNK2 rs6601105, JNK3 rs4693136, MEK2 rs10250, and ERK2 rs1063311) with nominally significant $(p<0.05) \mathrm{AD}$ association from the tau kinases pathway (Table 1), and examined the simultaneous effect of all these AD-associated risk alleles (genetic risk score, GRS) on the age of AD onset. In APOE non- $\varepsilon 4$ allele carriers, we found a statistically significant correlation $\left(r^{2}=0.177 ; p=0.001\right)$ between GRS and age at AD onset, and this correlation remained statistically significant after removing RPS6KB2 (intron 2, rs917570) from the analysis $\left(r^{2}=0.118, p=0.026\right)$; conversely, in APOE $\varepsilon 4$ allele carriers there was no correlation $\left(r^{2}=0.75 ; p=0.15\right)$ between GRS and age at onset. When age at AD onset was divided into quintiles (Fig. 1), GRS values increased significantly $(p=0.002)$ in late-onset $(>76$ years) patients, in the APOE non- $\varepsilon 4$ allele carriers; in contrast, there were no statistically significant GRS differences $(p=0.49)$ between quintile groups in APOE $\varepsilon 4$ allele carriers.

\section{DISCUSSION}

The largest genome-wide association study (GWA) in $\mathrm{AD}$ [11] did not find significant results for genes directly related to tau phosphorylation. However, it cannot be discarded that these genes in the tau kinases pathway are among the genes with significant nominal association but without reaching significance $\left(p<5 \times 10^{-8}\right)$ after adjustment for multiple testing in GWAs; in addition, it is also possible that some of the SNPs analyzed in our study were not present in the arrays used in GWAs or were lost during the strict quality control checks. Moreover, genes harboring markers with only modest evidence of association can be identified if they belong to the same biological pathway or mechanism; therefore, pathway-based approaches, which jointly consider multiple variants in interacting or related genes, might complement the most-significant SNPs/genes approach for interpreting GWA data on complex diseases $[12,13]$. In fact, genetic variation in the immune system and in lipid metabolism pathways is a cause of AD susceptibility $[14,15]$. Tau kinases genes can be divided into two major groups, i.e., the proline-directed tau kinases and non-proline-directed tau kinases (Fig. 2). The nonproline-directed tau kinases genes CAMK2A, MARKs (1, 2, 3 and 4), and PRKACB, were not associated with the $\mathrm{AD}$ risk in our study. Tau-tubuline kinase 1 (TTBK1) is another non-proline-directed kinase and 
Table 1

Minor allele frequencies distribution of tau kinases genes in AD patients and controls

\begin{tabular}{|c|c|c|c|c|c|c|c|}
\hline Gene & SNP & $\mathrm{MAF}, \mathrm{AD} / \mathrm{C}$ & $p$-value & Gene & SNP & $\mathrm{MAF}, \mathrm{AD} / \mathrm{C}$ & $p$-value \\
\hline \multirow[t]{5}{*}{ PRKACB } & rs6695305 & $0.45 / 0.46$ & 0.494 & $\mathrm{p} 38 \beta$ & rs2076139 & $0.18 / 0.19$ & 0.825 \\
\hline & rs6576960 & $0.45 / 0.46$ & 0.443 & IB 1 & rs 1554338 & $0.06 / 0.06$ & 0.838 \\
\hline & rs2250806 & $0.23 / 0.23$ & 0.773 & & rs7114162 & $0.30 / 0.30$ & 0.838 \\
\hline & rs12118723 & $0.44 / 0.45$ & 0.641 & JNK1 & rs 10857561 & $0.32 / 0.33$ & 0.312 \\
\hline & rs6695851 & $0.44 / 0.44$ & 0.917 & & rs 10857565 & $0.21 / 0.24$ & 0.033 \\
\hline \multirow[t]{12}{*}{ CAMK2A } & rs 10515639 & $0.24 / 0.25$ & 0.434 & & rs7086275 & $0.44 / 0.45$ & 0.677 \\
\hline & rs 13354653 & $0.20 / 0.21$ & 0.616 & JNK2 & rs12519649 & $0.12 / 0.14$ & 0.202 \\
\hline & rs13357922 & $0.36 / 0.37$ & 0.529 & & rs 17629029 & $0.25 / 0.24$ & 0.506 \\
\hline & rs4958445 & $0.27 / 0.28$ & 0.496 & & rs6601105 & $0.37 / 0.41$ & 0.009 \\
\hline & rs4958452 & $0.46 / 0.46$ & 0.900 & & rs3111515 & $0.40 / 0.41$ & 0.787 \\
\hline & rs3756577 & $0.14 / 0.14$ & 0.992 & & rs13185784 & $0.28 / 0.28$ & 0.743 \\
\hline & rs930212 & $0.40 / 0.40$ & 0.911 & & rs4147385 & $0.26 / 0.25$ & 0.439 \\
\hline & rs3776825 & $0.31 / 0.31$ & 0.833 & & rs4639174 & $0.18 / 0.16$ & 0.271 \\
\hline & rs3797617 & $0.18 / 0.17$ & 0.756 & & rs11955223 & $0.46 / 0.48$ & 0.432 \\
\hline & rs6869634 & $0.18 / 0.18$ & 0.616 & & rs6895740 & $0.35 / 0.35$ & 0.992 \\
\hline & rs10051644 & $0.26 / 0.27$ & 0.421 & JNK3 & rs4488910 & $0.14 / 0.15$ & 0.221 \\
\hline & rs17656349 & $0.40 / 0.42$ & 0.418 & & rs 12508801 & $0.16 / 0.17$ & 0.612 \\
\hline \multirow[t]{3}{*}{ MARK1 } & rs1933002 & $0.23 / 0.23$ & 0.916 & & rs7688651 & $0.38 / 0.38$ & 0.973 \\
\hline & rs 2378400 & $0.31 / 0.30$ & 0.455 & & rs7677400 & $0.16 / 0.16$ & 0.843 \\
\hline & rs12123306 & $0.45 / 0.43$ & 0.363 & & rs6826702 & $0.22 / 0.23$ & 0.314 \\
\hline MARK2 & rs4980530 & $0.35 / 0.37$ & 0.328 & & rs9307016 & $0.18 / 0.20$ & 0.316 \\
\hline \multirow[t]{3}{*}{ MARK3 } & rs1989565 & $0.35 / 0.34$ & 0.514 & & rs1460757 & $0.37 / 0.38$ & 0.348 \\
\hline & rs12896612 & $0.36 / 0.35$ & 0.615 & & rs6531905 & $0.25 / 0.25$ & 0.783 \\
\hline & rs9671414 & $0.30 / 0.32$ & 0.239 & & rs4403040 & $0.37 / 0.38$ & 0.555 \\
\hline \multirow[t]{3}{*}{ MARK4 } & rs12981145 & $0.51 / 0.49$ & 0.238 & & rs6821745 & $0.17 / 0.20$ & 0.058 \\
\hline & rs12984234 & $0.26 / 0.24$ & 0.235 & & rs4693136 & $0.16 / 0.12$ & 0.003 \\
\hline & rs11667235 & $0.31 / 0.28$ & 0.118 & & rs 12505566 & $0.18 / 0.20$ & 0.052 \\
\hline \multirow[t]{3}{*}{ CSNK1D } & rs7209167 & $0.42 / 0.43$ & 0.750 & & rs3775170 & $0.30 / 0.29$ & 0.570 \\
\hline & rs4789846 & $0.12 / 0.12$ & 0.935 & & rs2589518 & $0.16 / 0.13$ & 0.075 \\
\hline & rs11653735 & $0.18 / 0.20$ & 0.375 & MEK1 & rs8042644 & $0.11 / 0.09$ & 0.243 \\
\hline \multirow[t]{3}{*}{$\mathrm{CDC}^{*} *$} & rs2448347 & $0.41 / 0.44$ & 0.078 & & rs7181936 & $0.31 / 0.32$ & 0.938 \\
\hline & rs2456772 & $0.26 / 0.25$ & 0.775 & & rs8039880 & $0.20 / 0.19$ & 0.609 \\
\hline & rs1871447 & $0.27 / 0.24$ & 0.033 & MEK2 & rs350887 & $0.25 / 0.23$ & 0.423 \\
\hline \multirow[t]{5}{*}{ RPS6KB1 } & rs8071475 & $0.31 / 0.28$ & 0.023 & & rs350895 & $0.31 / 0.29$ & 0.415 \\
\hline & rs1292034 & $0.47 / 0.44$ & 0.173 & & rs350903 & $0.44 / 0.47$ & 0.108 \\
\hline & rs180531 & $0.24 / 0.24$ & 0.668 & & rs 10250 & $0.45 / 0.49$ & 0.033 \\
\hline & rs180515 & $0.32 / 0.33$ & 0.926 & & rs350911 & $0.32 / 0.33$ & 0.670 \\
\hline & rs1051424 & $0.14 / 0.15$ & 0.221 & & rs350916 & $0.45 / 0.47$ & 0.415 \\
\hline RPS6KB2 & rs917570 & $0.50 / 0.39$ & $1.24 \times 10^{-5}$ & ERK1 & rs7698 & $0.13 / 0.12$ & 0.726 \\
\hline \multirow{4}{*}{$\mathrm{p} 38 \alpha$} & rs851019 & $0.42 / 0.45$ & 0.041 & ERK2 & rs9610470 & $0.29 / 0.27$ & 0.377 \\
\hline & rs1100857 & $0.10 / 0.10$ & 0.477 & & rs1063311 & $0.51 / 0.47$ & 0.023 \\
\hline & rs16884919 & $0.09 / 0.09$ & 0.989 & & rs13515 & $0.22 / 0.20$ & 0.289 \\
\hline & rs3804452 & $0.14 / 0.16$ & 0.102 & & & & \\
\hline
\end{tabular}

$p$-values not corrected for multiple comparisons; in bold, significative $p$-values after multiple testing correction; ${ }^{*} \mathrm{CDC} 2$ AGC haplotype (rs2448347 G/A, rs2456772 G/C and rs1871447 C/T) was protective against AD.

Table 2

Haplotype association analysis between $\mathrm{CDC} 2$ gene and AD stratified by APOE $\varepsilon 4$ allele

\begin{tabular}{|c|c|c|c|c|c|c|c|c|c|}
\hline \multirow[b]{2}{*}{ Haplotype } & \multicolumn{3}{|c|}{ APOE $\varepsilon 4$ allele noncarriers } & \multicolumn{3}{|c|}{ APOE $\varepsilon 4$ allele carriers } & \multicolumn{3}{|c|}{ Total sample } \\
\hline & $\begin{array}{l}\mathrm{AD}, \text { control } \\
\text { frequency }\end{array}$ & $p$-value & $\begin{array}{c}\text { Permutation } \\
p \text {-value* }\end{array}$ & $\begin{array}{l}\mathrm{AD}, \text { control } \\
\text { frequency }\end{array}$ & $p$-value & $\begin{array}{c}\text { Permutation } \\
p \text {-value* }\end{array}$ & $\begin{array}{l}\mathrm{AD}, \text { control } \\
\text { frequency }\end{array}$ & $p$-value & $\begin{array}{c}\text { Permutation } \\
p \text {-value* }\end{array}$ \\
\hline$\overline{\mathrm{GGC}}$ & $0.34,0.31$ & 0.15 & 0.57 & $0.34,0.33$ & 0.75 & 1.00 & $0.36,0.33$ & 0.16 & 0.53 \\
\hline AGT & $0.27,0.22$ & 0.02 & 0.08 & $0.26,0.23$ & 0.42 & 0.97 & $0.26,0.23$ & 0.02 & 0.08 \\
\hline GCC & $0.23,0.20$ & 0.26 & 0.81 & $0.20,0.18$ & 0.49 & 0.99 & $0.22,0.21$ & 0.49 & 0.93 \\
\hline AGC & $0.09,0.15$ & $1.0 \times 10^{-4}$ & $1.0 \times 10^{-4}$ & $0.11,0.16$ & 0.06 & 0.27 & $0.11,0.18$ & $3.3 \times 10^{-7}$ & $3.0 \times 10^{-5}$ \\
\hline
\end{tabular}

Haplotype block consists of SNPs rs2448347 (intron 3), rs2456772 (intron 5), and rs1871447 (intron 7). Rare haplotypes (total frequency <0.05) were excluded from the analysis. * Multiple testing correction with 10,000 permutations. 


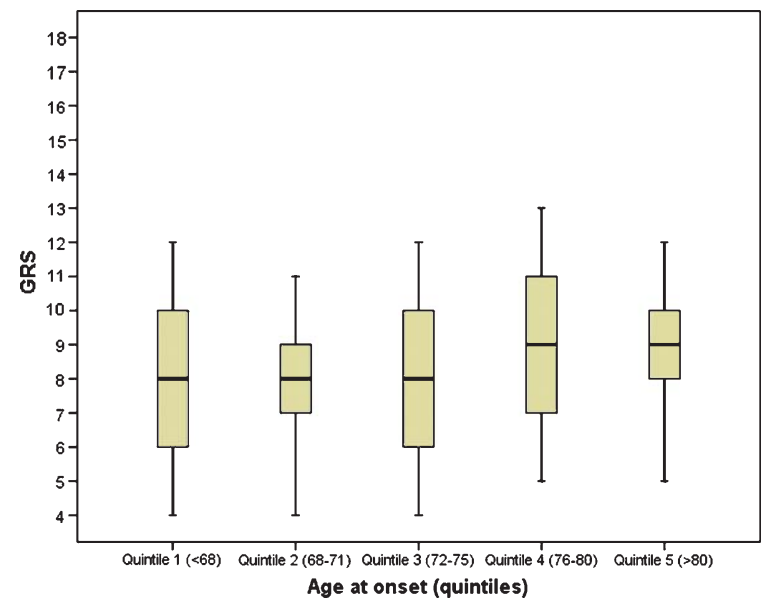

Fig. 1. Box plot showing correlation between age at $\mathrm{AD}$ onset divided into quintiles on the $\mathrm{x}$-axis and cumulative genetic risk score (GRS) on the y-axis, in APOE non- $\varepsilon 4$ allele carriers. GRS is defined as the number of nominally significant $(p<0.05)$ AD-associated risk alleles from our list of tau kinases pathway genes (CDC2 rs1871447, RPS6KB1 rs8071475, RPS6KB2 rs917570, p38 $\alpha$ rs851019, JNK1 rs10857565, JNK2 rs6601105, JNK3 rs4693136, MEK2 rs10250, and ERK2 rs1063311).

we recently [9] found that subjects carrying two copies of the minor allele of markers in introns 1,5 and 9 had a reduced risk of $\mathrm{AD}$; these findings have been replicated in Han Chinese [16]. The proline-directed tau kinases genes CSNK1D and the mitogen-activated protein kinase (MAPK) family comprising p38s ( $\alpha$ and $\beta)$, JNKs (1, 2 and 3) and its activator IB1, and ERKs (1 and 2) and their activators MEKs (1 and 2), were not associated with $\mathrm{AD}$ risk in the present study. However, the interaction between the minor allele of a polymorphism in the $5^{\prime}$ regulatory region $(-499$, rs1554338) of IB1 and either the major allele of LRP1 (exon 3, rs1799986) [17] or the minor allele of LRP8 (exon 19, rs5174) [18] has been associated with AD risk.

We have shown in this study, for the first time, that the RPS6KB2 (intron 2, rs917570) minor allele was associated with increased AD risk and a later onset of $\mathrm{AD}$, and that the combined effect of $\mathrm{AD}$-associated risk alleles from the genes of CDC2, RPS6KB1 and 2, p38 $\alpha$, JNK (1, 2 and 3), MEK2 and ERK2, was also associated with a later onset of AD, in APOE non$\varepsilon 4$ allele carriers. Late-onset AD patients might have a different genetic background compared with earlyonset $\mathrm{AD}$ patients that might enhance the effect of all these tau kinases pathway risk alleles, leading to a late expression of the disease. A polymorphism in the exon 6 (rs321239) of CDC2 was associated with AD risk in the Swedish population [19], and a haplotype derived from SNPs in exon 6 (rs321239) and exon 7 (rs2456777 and rs2456778) increased the risk of AD in APOE $\varepsilon 4$ carriers from Sicily [20], but a large study in Caucasian Americans failed to demonstrate this association [21]; conversely, a haplotype derived from SNPs in introns 3 (rs2448347), 5 (rs2456772), and 7 (rs1871447) of CDC2 showed a protective effect against AD in APOE $\varepsilon 4$ allele noncarriers in our population. The concentration of both activated CDC2 [22] and RPS6KBs [23] increases in AD brain and their distribution coincide with the progression of neurofibrillary degeneration.
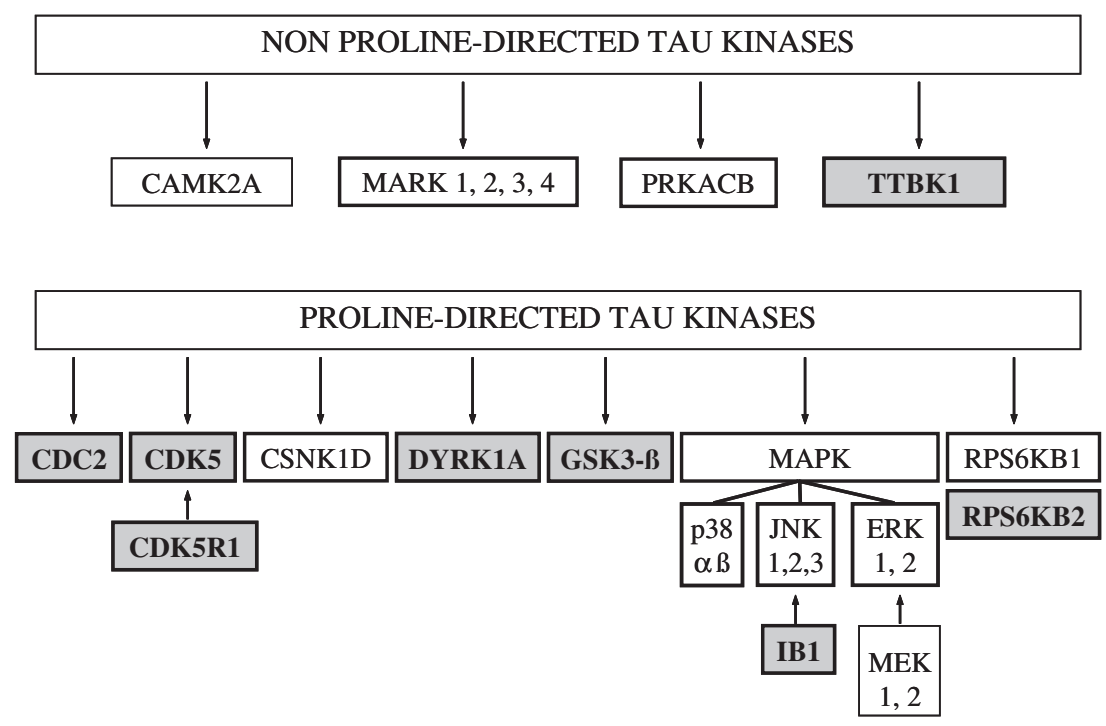

Fig. 2. Tau kinases genes analyzed in relation to Alzheimer's disease (AD) risk in both this study and the literature. In grey boxes, tau kinases genes associated to AD susceptibility. 
Possible mechanisms that contribute to the association between CDC2 and RPS6KBs polymorphisms and the risk of $\mathrm{AD}$ are unknown, as information about the expression of these proline-directed kinases at the brain level in subjects with different genotypes is lacking. The genes of the two major proline-directed kinases genes involved in the abnormal hyperphosphorylation of tau in AD, GSK3- $\beta$ and CDK5, have been associated with $\mathrm{AD}$ risk: subjects carrying the functional haplotype conformed by the minor allele of GSK3- $\beta(-50$, rs344558) and the major allele of GSK3- $\beta(-157$, rs6438552), independently [24] or in combination with at least one copy of the microtubule-associated protein tau $\mathrm{H} 2$ haplotype $[5,25]$, had an increase risk for AD. In a Dutch case-control series [26], the CDK5 haplotype composed of 5'UTR (rs2069442), intron 5 (rs2069454), intron 9 (rs891507 and rs2069459) and 3'UTR (rs9278) was significantly associated with AD in non-carriers of the APOE $\varepsilon 4$ allele, but these findings were not confirmed in our Spanish population [6]; however, we observed that a polymorphism in the 3'UTR region (rs735555) of the gene activator of CDK5 (CDK5R1) interacted with the major allele of GSK3- $\beta(-50$, rs344558) to decrease AD risk [7]. Finally, a haplotype with markers located from $30 \mathrm{~kb}$ upstream of exon 1 to exon 13 in the proline-directed tau kinase gene DYRK1A showed association with AD risk in the Japanese population [27], but we did not replicate this genetic association [8].

In the tau kinases pathway, our present negative results with the genes of PRKACB, CAMK2A, MARK (1, 2, 3 and 4), CSNK1D, p38 $\beta$, IB1, MEK1, and ERK1 are probably not due to insufficient statistical power, because our sample size had enough power $(>82 \%)$ to detect and odds ratio of 1.3 at disease allele frequencies of 0.20 . Conversely, our present positive findings suggest that CDC2 and RPS6KB2 are promising candidate tau phosphorylation-related genes for AD risk.

\section{ACKNOWLEDGMENTS}

C. Sánchez-Quintana was involved in the DNA sample collections from Santander. We also thank Drs. P. Gil and P. Coria for their cooperation in the generation of the case-control samples from Madrid. This work was made possible by the generous participation of the patients, the control subjects, and their families. This study was supported by grants from CIEN Foundation (PI019/09) and CIBERNED (CB06/07/0037).

Authors' disclosures available online (http://www.jalz.com/disclosures/view.php?id=910).

\section{REFERENCES}

[1] Ballatore C, Lee VMY, Trojanowski JQ (2007) Tau-mediated neurodegeneration in Alzheimer's disease and related disorders. Nat Rev Neurosci 8, 663-672.

[2] Wang JZ, Liu F (2008) Microtubule-associated protein tau in development, degeneration and protection of neurons. Prog Neurobiol 85, 148-175.

[3] Iqbal K, Grundke-Iqbal I (2008) Alzheimer neurofibrillary degeneration: Significance, etiopathogenesis, therapeutics and prevention. J Cell Mol Med 12, 38-55.

[4] Wang JZ, Grundke-Iqbal I, Iqbal K (2007) Kinases and phosphatases and tau sites involved in Alzheimer neurofibrillary degeneration. Eur J Neurosci 25, 59-68.

[5] García-Gorostiaga I, Sánchez-Juan P, Mateo I, RodríguezRodríguez E, Sánchez-Quintana C, Curiel del Olmo S, Vázquez-Higuera JL, Berciano J, Combarros O, Infante J (2009) Glycogen synthase kinase-3 $\beta$ and tau genes interact in Parkinson's and Alzheimer's diseases. Ann Neurol 65 , 759-761.

[6] Vázquez-Higuera JL, Mateo I, Sánchez-Juan P, RodríguezRodriguez E, Infante J, Berciano J, Combarros O (2009) No association of CDK5 genetic variants with Alzheimer's disease risk. BMC Med Genet 10, 68.

[7] Mateo I, Vázquez-Higuera JL, Sánchez-Juan P, RodríguezRodríguez E, Infante J, García-Gorostiaga I, Berciano. J, Combarros O (2009) Epistasis between tau phosphorylation regulating genes (CDK5R1 and GSK-3() and Alzheimer's disease risk. Acta Neurol Scand 120, 130-133.

[8] Vázquez-Higuera JL, Sánchez-Juan P, Rodríguez-Rodríguez E, Mateo I, Pozueta A, Frank A, Sastre I, Valdivieso F, Berciano J, Bullido MJ, Combarros O (2009) DYRK1A genetic variants are not linked to Alzheimer's disease in a Spanish case-control cohort. BMC Med Genet 10, 129.

[9] Vázquez-Higuera JL, Martínez-García A, Sánchez-Juan P, Rodríguez-Rodríguez E, Mateo I, Pozueta A, Frank A, Valdivieso F, Berciano. J, Bullido MJ, Combarros O (2011) Genetic variations in tau-tubulin kinase-1 are linked to Alzheimer's disease in a Spanish case-control cohort. Neurobiol Aging 32, 550.e5-550.e9.

[10] McKhann G, Drachman D, Folstein M, Katzman R, Price D, Stadlan EM (1984) Clinical diagnosis of Alzheimer disease: Report of the NINCDS-ADRDA Work Group under the auspices of the Department of Health and Human Services Task Force on Alzheimer Disease. Neurology 24, 939-944.

[11] Hollingworth P, Harold D, Sims R, Gerrish A, Lambert JC, Carrasquillo MM, Abraham R, Hamshere ML, Pahwa JS, Moskvina V, Dowzell K, Jones N, Stretton A, Thomas C, Richards A, Ivanov D, Widdowson C, Chapman J, Lovestone S, Powell J, Proitsi P, Lupton MK, Brayne C, Rubinsztein DC, Gill M, Lawlor B, Lynch A, Brown KS, Passmore PA, Craig D, McGuinness B, Todd S, Holmes C, Mann D, Smith AD, Beaumont H, Warden D, Wilcock G, Love S, Kehoe PG, Hooper NM, Vardy ER, Hardy J, Mead S, Fox NC, Rossor M, Collinge J, Maier W, Jessen F, Rüther E, Schürmann B, Heun R, Kölsch H, van den Bussche H, Heuser I, Kornhuber J, Wiltfang J, Dichgans M, Frölich L, Hampel H, Gallacher J, Hüll M, Rujescu D, Giegling I, Goate AM, Kauwe JS, Cruchaga C, Nowotny P, Morris JC, Mayo K, Sleegers K, Bettens K, Engelborghs S, De Deyn PP, Van Broeckhoven C, Livingston G, Bass NJ, Gurling H, McQuillin A, Gwilliam R, Deloukas P, Al-Chalabi A, Shaw CE, Tsolaki M, Singleton AB, Guerreiro R, Mühleisen TW, Nöthen MM, Moebus S, Jöckel KH, Klopp N, Wichmann HE, Pankratz VS, Sando SB, Aasly JO, Barcikowska M, Wszolek ZK, Dickson DW, Graff-Radford 
NR, Petersen RC; the Alzheimer's Disease Neuroimaging Initiative, van Duijn CM, Breteler MM, Ikram MA, Destefano AL, Fitzpatrick AL, Lopez O, Launer LJ, Seshadri S; CHARGE consortium , Berr C, Campion D, Epelbaum J, Dartigues JF, Tzourio C, Alpérovitch A, Lathrop M; EADI1 consortium, Feulner TM, Friedrich P, Riehle C, Krawczak M, Schreiber S, Mayhaus M, Nicolhaus S, Wagenpfeil S, Steinberg S, Stefansson H, Stefansson K, Snædal J, Björnsson S, Jonsson PV, Chouraki V, Genier-Boley B, Hiltunen M, Soininen H, Combarros O, Zelenika D, Delepine M, Bullido MJ, Pasquier F, Mateo I, Frank-Garcia A, Porcellini E, Hanon O, Coto E, Alvarez V, Bosco P, Siciliano G, Mancuso M, Panza F, Solfrizzi V, Nacmias B, Sorbi S, Bossù P, Piccardi P, Arosio B, Annoni G, Seripa D, Pilotto A, Scarpini E, Galimberti D, Brice A, Hannequin D, Licastro F, Jones L, Holmans PA, Jonsson T, Riemenschneider M, Morgan K, Younkin SG, Owen MJ, O’Donovan M, Amouyel P, Williams J (2011) Common variants at ABCA7, MS4A6A/MS4A4E, EPHA1, CD33 and CD2AP are associated with Alzheimer's disease. Nat Genet 43, 429-435.

[12] Wang K, Li M, Bucan M (2007) Pathway-based approaches for analysis of genomewide association studies. Am J Hum Genet 81, 1278-1283.

[13] Zhong H, Yang X, Kaplan LM, Molony C, Schadt EE (2010) Integrating pathway analysis and genetics of gene expression for genome-wide association studies. Am J Hum Genet 86, 581-591.

[14] Jones L, Holmans PA, Hamshere ML, Harold D, Moskvina V, Ivanov D, Pocklington A, Abraham R, Hollingworth P, Sims R, Gerrish A, Pahwa JS, Jones N, Stretton A, Morgan AR, Lovestone S, Powell J, Proitsi P, Lupton MK, Brayne C, Rubinsztein DC, Gill M, Lawlor B, Lynch A, Morgan K, Brown KS, Passmore PA, Craig D, McGuinness B, Todd S, Holmes C, Mann D, Smith AD, Love S, Kehoe PG, Mead S, Fox N, Rossor M, Collinge J, Maier W, Jessen F, Schürmann B, van den Bussche H, Heuser I, Peters O, Kornhuber J, Wiltfang J, Dichgans M, Frölich L, Hampel H, Hüll M, Rujescu D, Goate AM, Kauwe JS, Cruchaga C, Nowotny P, Morris JC, Mayo K, Livingston G, Bass NJ, Gurling H, McQuillin A, Gwilliam R, Deloukas P, Al-Chalabi A, Shaw CE, Singleton AB, Guerreiro R, Mühleisen TW, Nöthen MM, Moebus S, Jöckel KH, Klopp N, Wichmann HE, Rüther E, Carrasquillo MM, Pankratz VS, Younkin SG, Hardy J, O’Donovan MC, Owen MJ, Williams J (2010) Genetic evidence implicates the immune system and cholesterol metabolism in the aetiology of Alzheimer's disease. PLOS ONE 5, e13950.

[15] Lambert JC, Grenier-Boley B, Chouraki V, Heath S, Zelenika D, Fievet N, Hannequin D, Pasquier F, Hanon O, Brice A, Epelbaum J, Berr C, Dartigues JF, Tzourio C, Campion D, Lathrop M, Amouyel P (2010) Implication of the immune system in Alzheimer's disease: Evidence from genome-wide pathway analysis. J Alzheimers Dis 20, 1107-1118.

[16] Yu NN, Yu JT, Xiao JT, Zhang HW, Lu RC, Jiang H, Xing ZH, Tan L (2011) Tau-tubulin kinase-1 gene variants are associated with Alzheimer's disease in Han Chinese. Neurosci Lett 491, 83-86.
[17] Helbecque N, Abderrhamani A, Meylan L, Riederer B, Mooser V, Miklossy J, Delplanque J, Boutin P, Nicod P, Haefliger JA, Cottel D, Amouyel P, Froguel P, Waeber G (2003) Islet-brain 1/C-Jun N-terminal kinase interacting protein-1 (IB1/JIP-1) promoter variant is associated with Alzheimer's disease. Mol Psychiatry 8, 413-422.

[18] Helbecque N, Cottel D, Amouyel P (2009) Low-density lipoprotein receptor-related protein 8 gene polymorphisms and dementia. Neurobiol Aging 30, 266-271.

[19] Johansson A, Hampel H, Faltraco F, Buerger K, Minthon L, Bogdanovic N, Sjögren M, Zetterberg H, Forsell L, Lilius L, Wahlund LO, Rymo L, Prince JA, Blennow K (2003) Increased frequency of a new polymorphism in the cell division cycle 2 (cdc2) gene in patients with Alzheimer's disease and frontotemporal dementia. Neurosci Lett 340, 69-73.

[20] Bosco P, Caraci F, Copani A, Spada RS, Sortino MA, Salluzzo R, Salemi M, Nicoletti F, Ferri R (2007) The CDC2 I-G-T haplotype associated with the APOE $\varepsilon 4$ allele increases the risk of sporadic Alzheimer's disease in Sicily. Neurosci Lett 419, 195-198.

[21] Liang X, Schnetz-Boutaud N, Bartlett J, Anderson BM, Gwirtsman H, Schmechel D, Carney R, Gilbert JR, PericakVance MA, Haines JL (2007) Association analysis of genetic polymorphisms in the $\mathrm{CDC} 2$ gene with late-onset Alzheimer disease. Dement Geriatr Cogn Disord 23, 126-132.

[22] Pei JJ, Braak H, Gong CX, Grundke-Iqbal I, Iqbal K, Winblad B, Cowburn RF (2002) Up-regulation of cell division cycle (cdc) 2 kinase in neurons with early stage Alzheimer's disease neurofibrillary degeneration. Acta Neuropathol 104, 369-376.

[23] An WL, Cowburn RF, Li L, Braak H, Alafuzoff I, Iqbal K, Grundke-Iqbal I, Winblad B, Pei JJ (2003) Up-regulation of phosphorylated/activated p70 S6 kinase and its relationship to neurofibrillary pathology in Alzheimer's disease. Am J Pathol 163, 591-607.

[24] Zhang N, Yu JT, Yang Y, Yang J, Zhang W, Tan L (2011) Association analysis of GSK3B and MAPT polymorphisms with Alzheimer's disease in Han Chinese. Brain Res 1391, 147-153.

[25] Kwok JBJ, Loy CT, Hamilton G, Lau E, Hallupp M, Williams J, Owen MJ, Broe A, Tang N, Lam L, Powell JF, Lovestone S, Schofield PR (2008) Glycogen synthase kinase-3 $\beta$ and tau genes interact in Alzheimer's disease. Ann Neurol 64, 446454.

[26] Arias-Vásquez A, Aulchenko YS, Isaacs A, van Oosterhout A, Sleegers K, Hofman A, van Broeckhoven C, Oostra BA, Breteler M, van Duijn CM (2008) Cyclin-dependent kinase 5 is associated with risk for Alzheimer's disease in a Dutch population-based study. J Neurol 255, 655-662.

[27] Kimura R, Kamino K, Yamamoto M, Nuripa A, Kida T, Kazui H, Hashimoto R, Tanaka T, Kudo T, Yamagata H, Tabara Y, Miki T, Akatsu H, Kosaka K, Funakoshi E, Nishitomi K, Sakaguchi G, Kato A, Hattori H, Uema T, Takeda M (2007) The DYRK1A gene, encoded in chromosome 21 Down syndrome critical region, bridges between $\beta$-amyloid production and tau phosphorylation in Alzheimer disease. Hum Mol Genet 16, 15-23. 